\title{
Implementation Of Automated System For The Reservoir 66 of the Irrigation System Chambo Guano
}

\author{
Angel Silva C \\ Facultad de Informática y Electrónica, FIE \\ Escuela Superior Politécnica de Chimborazo, \\ ESPOCH \\ Riobamba, Ecuador \\ angelsilvaec@hotmail.com
}

\author{
Víctor Asanza, Nathaly Sánchez, Juan Arias \\ Facultad de Ingeniería en Electricidad y \\ Computación, FIEC \\ ESPOL \\ Guayaquil, Ecuador \\ \{vasanza, nssanche, jarias\}@espol.edu.ec
}

\begin{abstract}
This paper presents the control and monitoring of an automated system that is being implemented for the automation of a 66-irrigation reservoir located in Chambo Guano in the Chimborazo province, Ecuador. The Global System for Mobile communication / General Packet Radio Service (GSM) is used through a Long-Term Evolution (4G LTE) antenna and a communication module connected to a Programable Logic Controller (PLC) in order to notify the status of the valves, electric power troubles and the control signals for the correct operation of the irrigation system, so it can be done remotely. This project reflects how it is possible to obtain an efficient automated system with lower operating costs compared to the traditional and more importantly without having to move personnel to the control point for adjusting new conditions.
\end{abstract}

Keywords-Automation, Control, Controller, Programmable Logic, Efficiency, Scalability, Standard, Monitoring, Mechanism, Profinet, Red GSM, Industrial Network, Irrigation System, Remote Control, Valve.

\section{INTRODUCTION}

The Chambo Guano irrigation system is formed by a main pipe that supplies the vital liquid to several reservoirs located all the way through the water outlet for irrigation in the Chambo River to the main irrigation channel to the TB11 pipe, where the water conduction is done by gravity [1]

These irrigation processes would be handled in a better way if there were a system capable of opening and closing valves automatically, interacting with the maintenance managers of the system and keep a record of the irrigation activity by the flow variable, which is delivered to the irrigators. By improving the process, it can be quantified to what extent the water is used in the plots, taking in consideration the losses or in other words, the poorly used water [2].

Currently, an automatic system can achieve the characteristics of efficiency, reliability, stability, durability over time, but one of the most important characteristics is the scalability. The designed systems must provide, for easy adaptability, every consideration to satisfy future demands.

Supported by Escuela Superior Politécnica del Litoral (ESPOL) and NationalSecretariat of Higher Education, Science, Technology and Innovation of Ecuador (SENESCYT).
In the province of Chimborazo, it is urgent to have a system that allows to distribute water efficiently and equitably for the purposes of improving the diversification of agricultural production and the agriculture itself, articulated in the popular and solidarity economy. In this way it can be available, to users, the appropriate technology that will facilitate daily tasks, optimizing human resources [3].

The installation and commissioning of the control panel and monitors of Reservoir 66 of the Chambo Guano irrigation system has a wide justification based on Objective 3, Improving the quality of life of the population, of the National Plan for Good Living (2013-2017). The farmers who belong to the network that supplies this reservoir, will be benefited with irrigation water on schedule and with sufficient amount of liquid for the activity, reducing the waste of water by having shorter run times $[3,4]$.

The irrigation system has a defined process, however, climatic issues and the distancing of the reservoir often make it impossible for this empirical protocol for handling the reservoir to open and close manually every day to be carried out by the operators of these processes [5].

For the automation of the irrigation system and specifically the case of reservoir 66 , belonging to the Chambo Guano network, there is a 110VAC electrical wiring network. This voltage is insufficient to power equipment and actuators whose nominal value is $220 \mathrm{~V}$.

Another drawback is the frequency of power cuts because they are in remote places and prone to lightning strikes, producing faults in the power supply. Icite $\{\mathrm{b} 2\}$. The irrigation system, being a process of first necessity for the distribution of water in the agricultural area's sector, requires the safe operation of these systems [1]. However, despite all the preventive measures taken, there is always the possibility of water losses due to various factors, such as cracks in the wall of the pipe, defect in the joints, corrosion, wear, among others $[6,7]$.

There are problems with the lack of electrical power, caused by different reasons. These leaves the system out of service and therefore, unable to take any action of opening or closing at certain hours depending 
on the schedule, so the system must give a notification to those in charge of supervision [8].

The control panel, having a GSM terminal, can deliver a text message to the operator. In case of an emergency, the personnel goes to the reservoir and manually adjusts the physical conditions of the valves, avoiding both the lack of the resource to the beneficiaries of the irrigation system, and the waste of the vital liquid [9].

\section{RELATED WORKS}

In the reservoir 64 there is a control boardwith, a PLC communicated with an Arduino board by the transistorized digital signals. This process may be functional but not sustainable in a long term, since being equipment for different environments, the operation for the Arduino board is not optimal, causing the microcontroller be deprogrammed because of the presence of actuators with high current consumption [10].

Inside the board there is also a level sensor that provides feedback to control of the reservoir level but does not have a monitoring system to know the status of the level. Another stage installed inside the board is a bank of condensers that feed the arduino-based GSM electronic circuit for in case that happen a power cut this condenser bank supplies the circuit for a few moments until get send the warning of the lack of electrical supply [10].

One of the main disadvantages in the operative part of the prototype, is the low effectiveness in the delivery and reception of text messages due to the deprogramming of the arduino card. Leaving those in charge of reservoir maintenance without notification or control, so once again it is necessary the presence of the programmer to restore the board.

It is also necessary to take into account that the prototype works without variation in operating conditions, becoming a system with little capacity to adapt to new needs, except in the case of a new programming within the controller by a qualified technician in the specialty of automation industrial. The GSM technology at the national level is usually used for conventional communications by mobile operators for the exchange of data, calls and text messages [11].

Another study carried out in the country about the use of GSM network, is about the monitoring and acquisition of data from a meteorological station through the GPRS network. It is only monitored and acquired the variables using a GPRS communications module for PLC in the Telecontrol configuration for showing the results in a Supervision, Control and Data Acquisition (SCADA) software for its acronym in English, made in the WinCC flexible software 2008 $[8,12]$.

\section{METHODOLOGY}

\section{A. Reservoir's Initial Status}

The control system installed in the reservoir 66 consisted of a board that executed opening and closing routines of a butterfly valve, by a closed unconventional mechanism and little accessible to modifications that currently fulfilled its useful lifetime.

Therefore, it is considered necessary the presence frequent on-site personnel and manually intervention in the mechanical system. Over time the mechanical structure has been worn out. The distribution process was executed manually without any mechanism that helps reducing the efforts and investment of time by the employees in charge [13].

The operation was not appropiate, causing problems of operational and logistical nature due to the poor performance of the electrical and mechanical system. The implementation of the automatic system will provide reservoir 66 with an appropiate control of both the entry and the distribution of water (Fig. 1) by the mechanical systems connection to the main valves [14].

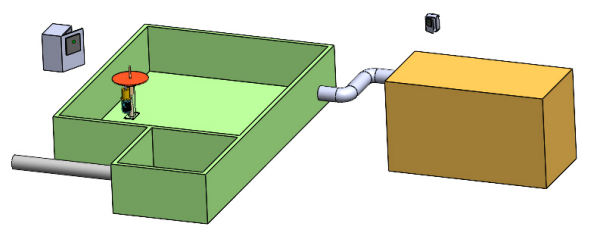

Figure 1. CAD representation of reservoir 66

\section{B. Control of water entry into the reservoir}

The cargo pipe to the reservoir has a butterfly valve (Fig. 2) that controls the opening, or the total closure for irrigation water, consists of an axis that is forced manually to open or close the valve in a considerable number of laps. Therefore, it is necessary to include a mechanism with reductor motor to have a better control of turn number of turns necessary for the opening or closing action, which depends on the level of the storage tank [15].

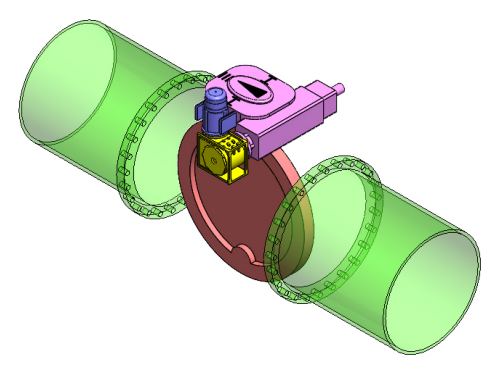

Figure 2. Butterfly valve 


\section{Control for water distribution}

For the execution of the automation in the distribution stage, it is essential to have a mechanical opening and closing system (Fig. 3). This will be commanded by a controller to execute the daily tasks in a repetitive manner, the mechanism is a reducer motor with a relation of adequate speed to overcome the resistance offered by the axis of the steering wheel by means of the screw in function to the weight and pressure that the water exerts on the gate.

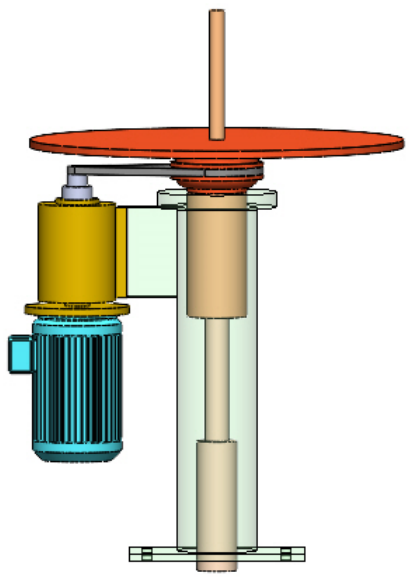

Figure 3. Butterfly valve

\section{Mechanical Design}

For the mechanical design of the systems, the variables present in the reservoir must be taken into consideration for the correct dimensioning of the actuators that will exert control actions on the mechanical structures as an adaptation to the existing ones. In the mechanism of the butterfly valve is not necessary mechanical study because the previous mechanism already incorporated a reducer motor with a power of $1 \mathrm{HP}$ but in a non-operational state, considering necessary only replace the previous engine with one of similar characteristics [11].

The design and study necessary (Table 1) to determine which is the suitable reducer motor for the mechanism of the gate requires information present in the reservoir itself, the variables measured below are detailed [16].

TABLE I. MEChANICAL DESIGIN

\begin{tabular}{|l|l|}
\hline \multicolumn{1}{|c|}{ Gate Features } & \multicolumn{1}{c|}{ Sizes } \\
\hline Width of the gate B & $1.10 \mathrm{~m}$ \\
Height of gate H & $1.10 \mathrm{~m}$ \\
Height of the Water's column H & $5 \mathrm{~m}$ \\
\hline Features of the worm & Sizes \\
\hline $\begin{array}{l}\text { External diameter of the worm } \\
\text { Screw Step }\end{array}$ & $11 / 2$ inch \\
Material & $4 \mathrm{~mm}$ double entry \\
\hline Characteristics of the chain and & steel \\
gear wheel & Sizes \\
\hline $\begin{array}{l}\text { Chain Number } \\
\text { Minor Wheel Diameter } \\
\text { Major Wheel Diameter }\end{array}$ & Step 70 \\
\hline
\end{tabular}

In order to be aware of the torque required for the reservoir gate to rise, it is necessary to evaluate the forces involved in it, such as the hydrostatic force produced in the gate as this is a plate submerged vertically in a column of water, as well as the force of friction generated to the movement by the contact of the gate, as well as the weight of the gate itself [17].

\section{E. Hydrostatic Force On The Gate}

Because the gate is considered as a flat plate submerged vertically, it will be exposed to the pressure of the water column which generates a hydrostatic force. The calculation of the hydrostatic force distributed per unit length is done with the equation:

$$
w=b \times h \times \rho \times g
$$

Where:

$$
\begin{gathered}
\mathrm{w}: \text { Hydrostatic force per unit length },(\mathrm{N} / \mathrm{m}) \\
\mathrm{b}: \text { Gate width, } b=1.10 \mathrm{~m} \\
\mathrm{~h}_{1}: \text { Height of the water column, } h_{1}=5 \mathrm{~m} \\
\mathrm{~h}_{2}: \text { Height of the water column, } h_{2}=6.1 \mathrm{~m} \\
\rho: \text { Water density, } \rho=1000 \mathrm{~kg} / \mathrm{m}^{3} \\
\mathrm{~g}: \text { Gravitational Acceleration, } \mathrm{g}=9.8 \mathrm{~m} / \mathrm{s}^{2}
\end{gathered}
$$

Replacing this equation, we have:

$$
w_{1}=b \times h_{1} \times \rho \times g
$$

$$
\begin{gathered}
w_{1}=1.10 \mathrm{~m} \times 5 \mathrm{~m} \times 1000 \frac{\mathrm{kg}}{\mathrm{m}^{3}} \times 9.8 \frac{\mathrm{m}}{\mathrm{s}^{2}} \\
w_{1}=53900 \frac{\mathrm{N}}{\mathrm{m}} \\
w_{2}=b \times h_{2} \times \rho \times g \\
w_{2}=1.10 \mathrm{~m} \times 6.10 \mathrm{~m} \times 1000 \frac{\mathrm{kg}}{\mathrm{m}^{3}} \times 9.8 \frac{\mathrm{m}}{\mathrm{s}^{2}} \\
w_{2}=65758 \frac{\mathrm{N}}{\mathrm{m}}
\end{gathered}
$$

The total hydrostatic force is given by:

$$
F_{h}=w_{1} \times l_{1}+\frac{\left(w_{2}-w_{1}\right) \times l_{1}}{2}
$$

$$
\begin{aligned}
F_{h} & =53900 \frac{N}{m} \times 1.10 m+\frac{\left(65758 \frac{N}{m}-53900 \frac{N}{m}\right) \times 1.10 m}{2} \\
F_{h} & =53900 \frac{N}{m} \times 1.10 m+\frac{\left(65758 \frac{N}{m}-53900 \frac{N}{m}\right) \times 1.10 m}{2}
\end{aligned}
$$

\section{F. Friction Force Of The Gate When Going Up}

By the movement of the gate when going up or down and by being in contact with another surface, this will generate friction forces opposed to the movement, these forces will be part of the load to raise 
the gate, and this is calculated by middle of the equation [18]:

$$
F_{r}=N \times \mu_{k}
$$

Where:

$$
\begin{gathered}
\mathrm{f}_{r}: \text { Friction Force },(N) \\
\mathrm{N}: \text { Normal force to friction surface } \\
\mathrm{N}=65811.9(\mathrm{~N}) \\
\mu_{k}: \text { kinetic friction coefficient (Metal Metal) } \\
\mu_{k}=0.40
\end{gathered}
$$

TABLE II. COEFFICIENTS OF Friction

\begin{tabular}{|l|l|}
\hline \multicolumn{1}{|c|}{ Area } & Coefficients of friction \\
\hline Metal above metal & $0.15-0.60$ \\
Metal above wood & $0.20-0.60$ \\
Metal above stone & $0.30-0.70$ \\
Metal above leather & $0.30-0.60$ \\
Wood above wood & $0.25-0.50$ \\
Wood above leather & $0.25-0.50$ \\
Stone above stone & $0.40-0.70$ \\
Earth on earth & $0.20-1.00$ \\
Rubber above concrete & $0.60-0.90$ \\
\hline
\end{tabular}

The normal force is considered equal to the hydrostatic force of the system and considering that the gate slides on a steel surface, the coefficient of kinetic friction (Table 2) will be approximately 0.40 , having:

$$
F_{r}=65811.9(N) \times 0.40=26324.8(N)
$$

\section{G. Load For The Power Screw}

The load that the system will raise is equal to the sum of the friction force present that was calculated previously and the weight of the gate that is obtained from the modeling performed in the SolidWorks software [19].

$$
F_{C}=m
$$

Where:

$$
\begin{gathered}
\mathrm{f}_{c}: \text { Weight of the gate },(N) \\
\mathrm{m}: \text { Gate Mass, } \mathrm{m}=130 \mathrm{~kg} \\
\mathrm{~g}: \text { Gravitational Acceleration, } g=9.8 \frac{\mathrm{m}}{\mathrm{s}^{2}} \\
F_{C}=130 \mathrm{Kg} \times 9.8 \frac{9.8 \mathrm{~m}}{\mathrm{~s}^{2}}=1274(\mathrm{~N})
\end{gathered}
$$

Therefore, the load that the system will have to raise will be:

$$
F=F_{r}+F_{c}=26324.8 N+1274 N=27598.8(N)
$$

To realize the design of the power screw it is necessary to know which is the load to lift and if it goes up and down with load or goes up with load and low without load, in addition to knowing the material of the screw and the nut, as well as what type of Thread is the power screw [20].

\section{H. Torque Necessary To Raise And Lower The Gate}

To allow the power screw to raise the load or lower it, a torque is required, which is generated by a motor, these torques can be calculated with the following equations:

$$
\begin{aligned}
& T_{s}=\frac{F_{m}}{2} \times\left(\frac{\mu \times \pi_{m}+\rho}{\pi_{m}-\mu \times \rho}\right)+\frac{F_{c} \times \mu_{c}}{2} \\
& T_{b}=\frac{F_{m}}{2} \times\left(\frac{\mu \times \pi_{m}-\rho}{\pi_{m}+\mu \times \rho}\right)+\frac{F_{c} \times \mu_{c}}{2}
\end{aligned}
$$

Where:

$$
\begin{aligned}
& \mathrm{T}_{s}: \text { Torque to raise the load, }(\mathrm{Nm}) \\
& \mathrm{T}_{b}: \text { Torque to lower the load, }(\mathrm{Nm})
\end{aligned}
$$

F : Load applied to power screw, $F=27.6 \mathrm{kN}$

$\mathrm{d}_{m}$ : Average diameter of power screw, $(\mathrm{mm})$

$$
\mathrm{d}_{c}: \text { Collar diameter, } d_{c}=42 \mathrm{~mm}
$$

$\mu$ : Coefficient of friction (screw \& nut),

$$
\mu=0.08
$$

$\mu_{c}$ : Coefficient of friction (screw \& collar),

$$
\mu_{c}=0.08
$$

$\rho:$ Advance of screw for each turn, $\rho=8 \mathrm{~mm}$

We calculate the average diameter of the screw:

$$
d_{m}=d-\frac{p}{2}
$$

Where:

$$
\begin{gathered}
\mathrm{d}: \text { Larger diameter of Power Screw } \\
\mathrm{d}=38 \mathrm{~mm} \\
\mathrm{p}: \text { Step of Screw, } p=4 \mathrm{~mm} \\
d_{m}=38 \mathrm{~mm}-\frac{4 \mathrm{~mm}}{2}=36 \mathrm{~mm}
\end{gathered}
$$

Replacing in the torque equation (16), we have:

Replacing in the torque equation (17), we have:

$$
T_{b}=\frac{\frac{0.08 \times \pi \times 32 \mathrm{~mm}-8 \mathrm{~mm}}{\pi \times 32 \mathrm{~mm}+0.08 \times 8 \mathrm{~mm}}}{\frac{2}{27.6 \mathrm{kN} \times 32 \mathrm{~mm}}}+\frac{27.6 \mathrm{kN} \times 42 \mathrm{~mm} \times 0.08}{2}
$$

$$
T_{b}=0.2 N m+46.3 N m=46.5 N m
$$

$T_{s}$

$$
\begin{gathered}
\sigma_{e q_{m}}=\sqrt{(30.3 M P a)^{2}+3 \times(10.6 M P a)^{2}} \\
\sigma_{e q_{m}}=35.4 M P a \\
T_{s}=71.0 \mathrm{Nm}+46.4 \mathrm{Nm}=117.4 \mathrm{Nm}
\end{gathered}
$$

\section{Design And Electrical Assembly}

The automatic control system is based on a cabinet with dimensions $60 \times 40 \times 20$, inside are installed elements of protection, sensors, controller, user interface and power stage. Depending on the required power calculated for the mechanical system operation, the use of protections for the entire electrical system is required.

The maximum current of consumption in the network of a three-phase motor by the frequency 
inverter is 19.4 amps, it is a high current that, in a certain way, compensates the lack of voltage in the network with the ratio, at lower voltage higher current consumption with a three-phase motor operating at $220 \mathrm{~V}$ three-phase grid, this voltage is obtained through the frequency inverter from a single-phase $110 \mathrm{~V}$ network $[22,23]$.

A fully automated system is considered as a process that incorporates a memory unit capable of acquiring the variables and processing them to obtain an output, based on one or several objectives. The control board incorporates a PLC that executes instructions recorded by the programmer to comply with the process of opening and closing the main valves of the reservoir [11].

The PLC also offers security to the mechanisms and actuators through the program in such a way that, if the operator does not realize the state of the valve and repeats the process, it can seriously damage the actuators and / or damage the mechanisms, because a valve that, for example, if it is closed it cannot be closed again or vice versa. As an additional protection to the relay contacts incorporated in the PLC, some rels with a $24 \mathrm{VDC}$ coil and contacts that support up to 10 Amp have been installed [19].

\section{J. Assembly And Start Up Of The Module Of GSM + Antenna 4G LTE Communications}

The control and monitoring to which users can easily access is through text messages according to their recommendation. For this reason, a communication system was implemented through the GSM network by accessing it through a module of communications CP1242-7 of industrial standard, compatible with the PLC S7 1200.

\section{RESULTS}

\section{A. Efficiency}

The margin of savings is directly related to the efficiency of the system because a timely response saves time and money not only to those in charge of the irrigation system, but also to the beneficiaries or irrigators. The reservoir 66 does an efficient job in performing the same task of opening and closing valves in a much shorter time without the need to mobilize personnel.

\section{B. Standardization of irrigation processes}

When mentioning the standardization of the irrigation processes, it is necessary to verify the service conditions and current state of the reservoirs to analyze to what extent it is possible to achieve standardization of the automated process. Understanding that it will be done with the same devices, or equipment's, to control actuators of similar characteristics. In the case of the reservoirs belonging to the irrigation system that starts in TB11, all are in conditions to be standardized because the automatic system of the reservoir 66 works in both $110 \mathrm{Vac}$ and $220 \mathrm{Vac}$. This means that the same control panel can be compatible with the conditions of any other reservoir within the Chambo Guano irrigation network.

\section{Scalability of the control panel}

The control panel installed in the reservoir 66 offers the scalability feature, it can accept more variables of future processes because of the modem and the mobile antenna, that can send and receive a list of instructions that allows to manage more resources. The fundamental key to the scalability to which the system can be submitted is that, due to some need, it changes its way of operating, but without losing the quality of the management of the information that, within the network is used to execute the processes properly.

\section{Control for the flow delivered to users}

The flow delivered to the users at present cannot be quantified because the equipment that performed the processing of that data have fulfilled their useful life time, for this reason it is proposed to measure the flow by means of the pressure in the pipes in difference with the help of a Venturi's tube installed in each reservoir in a deficient state of operation.

\section{CONCLUSIONS}

The installation of the control panel for the entrance of water to the reservoir avoids the waste of the water because of the acquisition of the level of the tank and the positioning of the valve with the help of industrial instrumentation, achieving that other reservoirs can be filled in less time.

The control system for the distribution of water to users, opens and closes the gate valve at the scheduled times, establishing an order in the irrigation planning. The results of the design and construction of the mechanical couplings and sizing of the reducer motor for the butterfly and gate valves work correctly, enabling the valves to execute the corresponding actions, overcoming the resistance offered by the valves.

The delivery of notifications of the status of the valves is of great help for the operators because their presence is not necessary to verify the mechanical conditions of the processes. As future work it is proposed to carry out a previous stage of identification of open loop system that allows us to understand adequately modeling the automatic irrigation system [23].

\section{REFERENCES}

[1] BEER, F. P., \& JOHNSTON, R. E. (2010). Mecánica Vectorial para ingenieros. Mexico: McGrawHill.

[2] Beer, F. P., Johnston, E. R., Mazurek, D. F., Cornwell, P. J., \& Eisenberg, E. R. (2009). Vector mechanics for engineers Statics and Dynamics. New York: McGraw Hill.

[3] Castillo, B. A. S., Calderón, J. D. C., \& Hualpa, R. A. (2020). Aplicación para el diseño paramétrico de un prototipo de bomba de pistón alternativa y sumergible. Revista Arbitrada Interdisciplinaria Koinonía, 5(9), 223-248.

[4] Castro Burgos, L., \& Valdés-González, H. (2009). Detección de pérdidas en tuberías de agua: Propuesta basada en un banco de filtros. Ingeniare. Revista chilena de ingeniería, 17(3), 375-385.

[5] Mejía-Neira, Á., Jabba, D., Caballero, G. C., \& CaicedoOrtiz, J. (2019). Influencia de la Ingeniería de Software en los Procesos de Automatización Industrial. Información tecnológica, 30(5), 221-230. 
[6] Chasi Sisa, E. B., \& García Samaniego, P. D. R. (2019). Modelo organizacional de la unidad de Gestión de Riesgos en el Cuerpo de Bomberos del Gobierno Autónomo Descentralizado Municipal del cantón Riobamba, año 2017 (Bachelor's thesis, Universidad Estatal de Bolívar. Facultad de Ciencias de la Salud y del Ser Humano... Carrera de Adminoistración para Desastres y Gestión de Riesgo).

[7] JURECHG. (2016). JUNTA GENERAL DE USUARIOS DE RIEGO CHAMBO GUANO. Recuperado el 15 de 07 de 2016, de \%JURECHG: http://jurech.org.ec/

[8] Maldonado, D. (2013). Repositorio Universidad del Azuay. Recuperado el 14 de Febrero de 2016, de Repositorio Universidad del Azuay: http://dspace.uazuay.edu.ec/bitstream/datos/2193/1/09655.pdf

[9] María del Mar, H. (2015). LA GESTIÓN DE LOS RECURSOS HIDRICOS EN LA ADAPTACIÓN AL CAMBIO CLIMATICO. ieee.es, 10.

[10] Miranda, H. (2015). DISEÑO Y CONSTRUCCIÓN DE UN PROTOTIPO PARA CONTROL Y MONITOREO DE RESERVORIOS DE AGUA EMPLEANDO COMUNICACIÓN MÓVIL GSM/GPRS EN SISTEMAS DE RIEGO. SATHIRI, 193 - 201.

[11] Norton, R. L. (2011). Diseñó de maquinas un enfoque integrado. Mexico: Pearson.

[12] Zuleta Muñoz, F. A. (2019). Diseño y Acondicionamiento del Sistema Automático de una Planta de Tratamiento de Agua Residuales.

[13] REXNORD. (14 de Septiembre de 2016). Rexnord cadenas y coronas. Obtenido de http://www.rexnord.com

[14] Frizziero, L., Liverani, A., Caligiana, G., Donnici, G., \& Chinaglia, L. (2019). Design for disassembly (DfD) and augmented reality (AR): case study applied to a gearbox. Machines, 7(2), 29.

[15] Romero, G., Salazar, C., \& Asanza, V. (2015). Desarrollo de un Prototipo de Sistema Hidrometeorológico. Revista Tecnológica-ESPOL, 28(5).
[16] SENPLADES. (2013). Territorio y descentralización: competencia de riego y drenaje. Recuperado el 03 de Enero de 2015, de http://www.planificacion.gob.ec/wpcontent/uploads/downloads/2014/01/Territorio-yDescentalizaci\%C3\%B3n-Riego-Drenaje.pdf

[17] Usta, S., Gençoğlan, S., \& Gençoğlan, C. (2019). Establishing the Flow Charts that can be Used in the Design of Irrigation Automation Systems. Turkish Journal of Agriculture-Food Science and Technology, 7(7), 1014-1020.

[18] Cordova, R., Garcia, I. M., Munoz-Arcentales, A., Asanza, V., \& Vargas, W. A. V. (2018). Modelo de red de comunicación que soporta un sistema de detección basado en criterios de robustez. IEEE Latin America Transactions, 16(10), 2600-2608.

[19] Cevallos Rodriguez, H. D., \& Gualacio Padilla, J. L. (2017). Implementación de un sistema de control y monitoreo a distancia en procesos de ensamblaje con robot industrial Kawasaki RS003 por medio de la red GSM en el Laboratorio de Automatización Industrial de la Facultad de Mecánica (Bachelor's thesis, Escuela Superior Politécnica de Chimborazo).

[20] Pérez-Leira, R., \& Domínguez-Gutiérrez, J. (2019). El régimen de riego para cultivos en Manabí, Ecuador: propuesta para cinco cultivos permanentes. Revista Ciencias Técnicas Agropecuarias, 28(4).

[21] Martín, J. C., \& García, M. P. (2016). Automatismos industriales cableados (Automatismos industriales). Editex.

[22] González-Filgueira, G., \& Permuy, F. J. R. (2018). Automatización de una planta industrial de alimentación mediante control distribuido. RISTI-Revista Ibérica de Sistemas e Tecnologias de Informação, (27), 1-17.

[23] Asanza, V., Martín, C. A., Eslambolchilar, P., van Woerden, H., Cajo, R., \& Salazar, C. (2017, October). Finding a dynamical model of a social norm physical activity intervention. In Ecuador Technical Chapters Meeting (ETCM), 2017 IEEE (pp. 1-6). IEEE. 